\title{
Upper Pliocene to Lower Pleistocene plant microfossils from the basal part of the Lukundol Formation (southern Kathmandu valley) and their climatic implications
}

\author{
*Maria Maharjan, Sima Humagain, and Khum N. Paudayal \\ Central Department of Geology, Tribhuvan University, Kirtipur, Kathmandu, Nepal
}

\begin{abstract}
The Late Pliocene to Lower Pleistocene fluvio-lacustrine sediments of the Lukundol Formation distributed in the southern part of the Kathmandu Basin, consists of various fossils of flora and fauna which are very useful proxies to reconstruct the past climate. Twenty seven samples were collected for palynological study from different beds of the Lukundol Formation exposed in the Pharsidol area due to recent road cut. The exposure is about $100 \mathrm{~m}$ thick. The study revealed the dominance of gymnosperms over angiosperm plants. On the basis of the pollen assemblage, the Lukundol Formation could be divided into three different pollen zones namely PD-I, PD-II and PD-III. The variation in the climate observed in these three zones indicates that the climate of the Kathmandu valley during the deposition of the Lukundol Formation was not uniform. The climate had been warmer in the lower and upper zones while colder in the middle zone than today.
\end{abstract}

Key words: Pliocene-Pleistocene, vegetation, climate, Kathmandu

Received: 13 March 2018

Accepted: 25 June 2018

\section{INTRODUCTION}

Kathmandu Basin is one of the largest intermontane basins, unconformably lying over the rock of the Lower Paleozoic Phulchauki Group. The basin fill sediments provide an unique opportunity to study the past climate change based on plant fossils (Paudayal 2011a). The basin lies within the Lesser Himalaya and bounded by Phulchauki hill in the south and Shivapuri hill in the north. It is filled by the thick sequence of lacustrine and fluvial deposits, ranging in age from Neogene to Quaternary Periods (Yoshida and Igarashi 1984). Geologically, Kathmandu Basin sediments have been divided into different lithostratigraphic units by different researchers (Yoshida and Igarashi 1984; Yoshida and Gautam 1988; Dongol 1985, 1987; Sah et al. 1995; Sakai 2001; Sakai et al. 2008). The basin is divided into seven stratigraphical units. Lukundol Formation is the oldest deposit ranging in age from Late Pliocene to Lower Pleistocene (Yoshida and Gautam 1988). The Chapagaon, Boregaon, and Pyangaon Terrace Deposits are mostly distributed in the southern part of the basin. The Gokarna, Thimi and Patan formations are the youngest deposits found at the northern part. The first stratigraphic division of these sediments was proposed by Yoshida and Igarashi (1984). Later, Paudel and Sakai (2008) stratigraphically divided southern Kathmandu valley sediments into 6 units such as Tarebhir, Lukundol, Sunakothi, Itaiti formations, Terrace Gravel Deposit and Kalimati Formation from older to younger. Many researchers have done the palynological and macrofossil study in the northern and southern parts of the Kathmandu valley

*Corresponding author

Email: mariyamaharjan@gmail.com (M. Maharjan) sediments (Kral and Havinga 1979; Mittre and Sharma 1984; Yoshida and Igarashi 1984; Fuji and Sakai 2002; Paudayal and Ferguson 2004; Paudayal 2005, 2006, 2011a, 2011b; Bhandari et al. 2009, 2010). The first palynological study from the Lukundol Formation was done by Yoshida and Igarashi (1984) and Igarashi et al. (1988) and explored the great potential for using plant microfossils to study the past climate from this area. Bhandari and Paudayal (2007) carried out palynological study in the Khahare Khola section of the Lukundol Formation. The present study is carried from a surface exposure at Pharsidol belonging to the same formation (Fig. 1). Recently the basal part of this formation is exposed due to road cut which enabled us to take fresh samples for palynological study (Fig. 2).

\section{GEOLOGY}

\section{Lukundol Formation}

The Lukundol Formation is the oldest of the Kathmandu Basin sediments, well exposed in the southern part around Pharsidol, Tokalmat, Lukundol, Naikhandi, Sunakothi, along the Khahare Khola, Bagmati River and Nakkhu Khola (Yoshida and Igarashi 1984). Dhoundial (1966) first named this formation as Lukundol after the Lukundol village. The main lithology of the Lukundol Formation is sand, silt, gravel, clay and lignite. The basal part of this formation consists of conglomerates with pebbles and cobbles of quartize, slate, phyllite, granite and limestone. This is considered as the lower member of Lukundol Formation by Dongol (1985) and West et al. (1988). The conglomerate beds are considered as a separate formation i.e. Tarebhir Formation by Sah et al. (1995) and Sakai 
Maharjan et al.

$80^{\circ} 00^{\prime}$

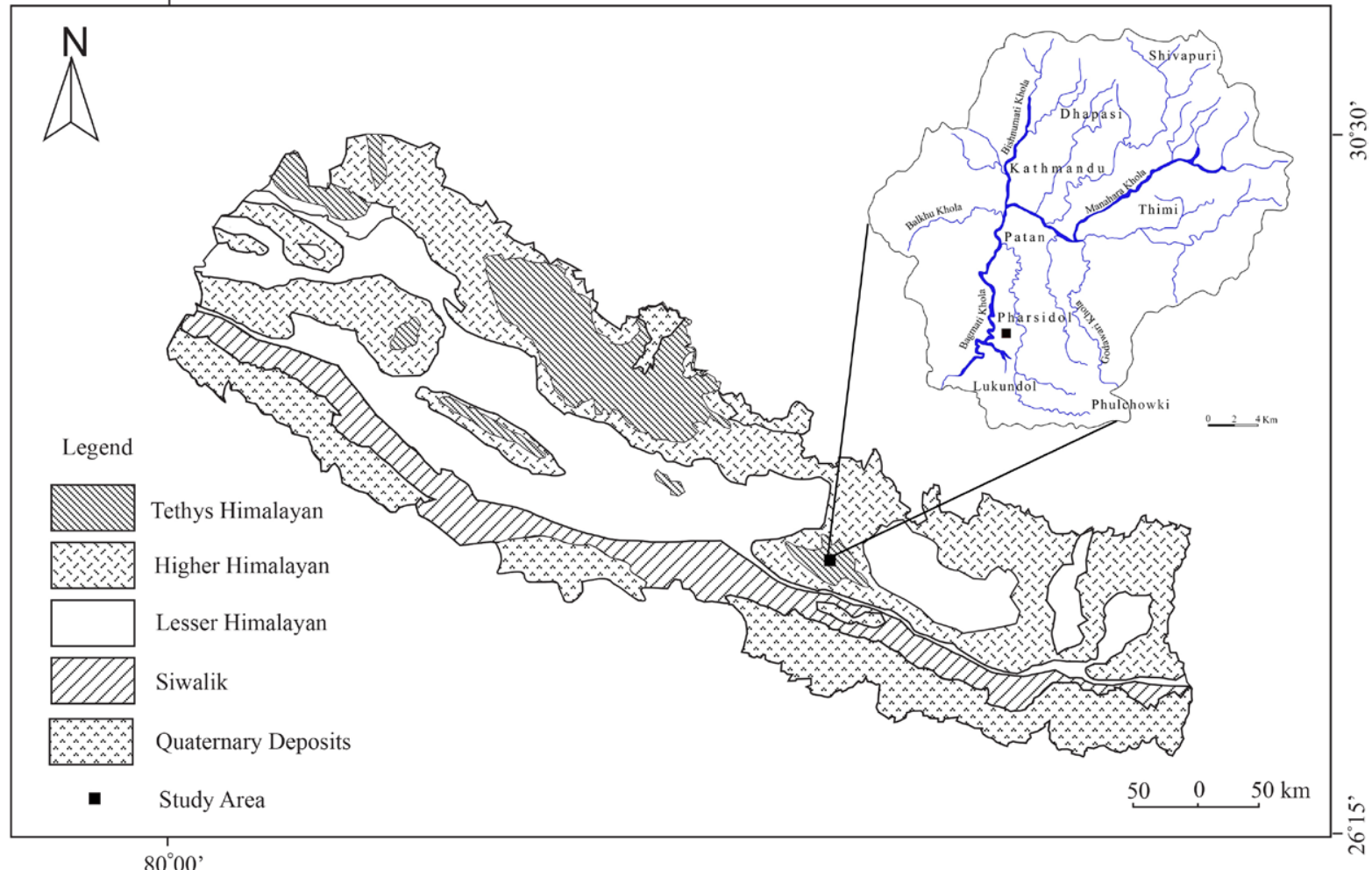

Fig. 1: Location of the study area.

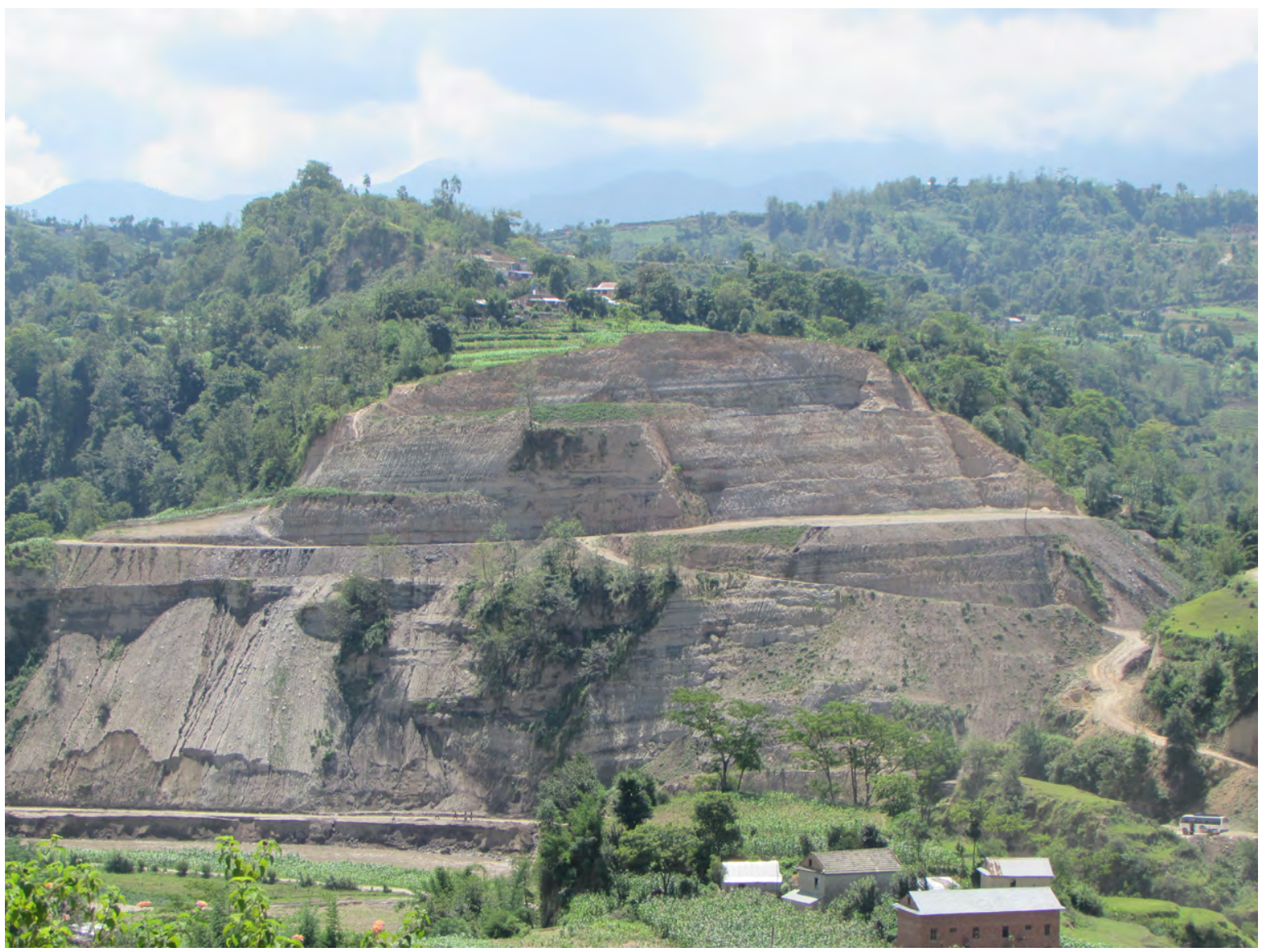

Fig. 2: Aerial view of the surface exposure of the Lukundol Formation (basal part) at Pharsidol. 
(2001). The sediments of the Lukundol Formation is estimated to have deposited from Gauss Chron to early Brunhes Chron, i.e. older than $2.58 \mathrm{Ma}$ which range from Late Pliocene to the Lower Pleistocene in age (Yoshida and Gautam 1988).

Recently the basal part (about $100 \mathrm{~m}$ ) of this formation is well exposed above the basement rock near the Pharsidol area due to a road construction (Figs. 3-4a). The lower part of the measured section is sand dominated. It consists of gravel, coarse to fine grained sand, silt, and layers of lignite The middle portion is silty clay and clay dominated. About $1 \mathrm{~m}$ thick diatomaceous layer is present in the middle portion of this formation which indicates the lacustrine environment as these layers are deposited mostly in such environment (Fig. $4 \mathrm{~b})$. Frequent lignite beds are common. The sedimentary structures such as cross bedding (Fig. 4c), synsedimentary fault (Fig. 4d), climbing ripples and flow structures (Fig. 4e) were observed in this section. Cross beddings and climbing ripples indicate fluvial nature of sedimentation. Three small scale synsedimentary faults and flow structures were observed on the sand bed which indicate influence of tectonic activity at the time of deposition of Lukundol Formation. The upper part is gravel, sand and silt dominated (Fig. 4f). The gravel bed consisted of vertebrate bone fragments. Frequent gravel layers indicate fluvial influence during deposition of the Lukundol Formation. Plant debris, fossilized tree trunks are common in this section. The fossil fruits Trapa quadrispinosa are abundant in the clay and silty clay layers.

\section{MATERIAL AND METHODS}

A total number of 27 samples were collected for pollen analysis from lignite and nearly all the fine-grained sediments such as clay, diatomaceous clay and silty clay layers of the Lukundol Formation exposed at the Pharsidol area. The samples were prepared with a series of chemical treatments to extract the organic residue from the sediments at the Central Department of Geology, Tribhuvan University following the method described by Ferguson et al. (2007). The samples had to be treated with conc. acids such as hydrochloric acid, hydrofluoric acid, acetic acid, acetolysis solution (9:1 acetic anhydride and sulphuric acid) and finally with heavy liquid (zinc chloride with specific gravity 2 ) to extract organic matter from the inorganic fraction. The organic matter thus obtained were suspended in glycerin and examined under OLYMPUSBX43 system light microscope under 10x, 20x, 40x and 60x objectives and the photographs were taken under $60 \mathrm{x}$ objective with an OLYMPUS DP-20 digital camera mounted to the microscope and a computer software DP2-BSW was used. At least 200 pollen grains were point counted from each sample identifying and listing them in a standard chart. The percentage of individual taxa from each sample was calculated and plotted against the sample horizon to make a pollen diagram with the help of TILIA software. The identification of pollen and spores were mainly based on publications such as Wang et al. (1995); Gupta and Sharma (1986); Academic Sinica (1982); Paudayal (2005, 2006, 2011a, 2011b); Punt et al. (1994) and Hesse et al. (2009).

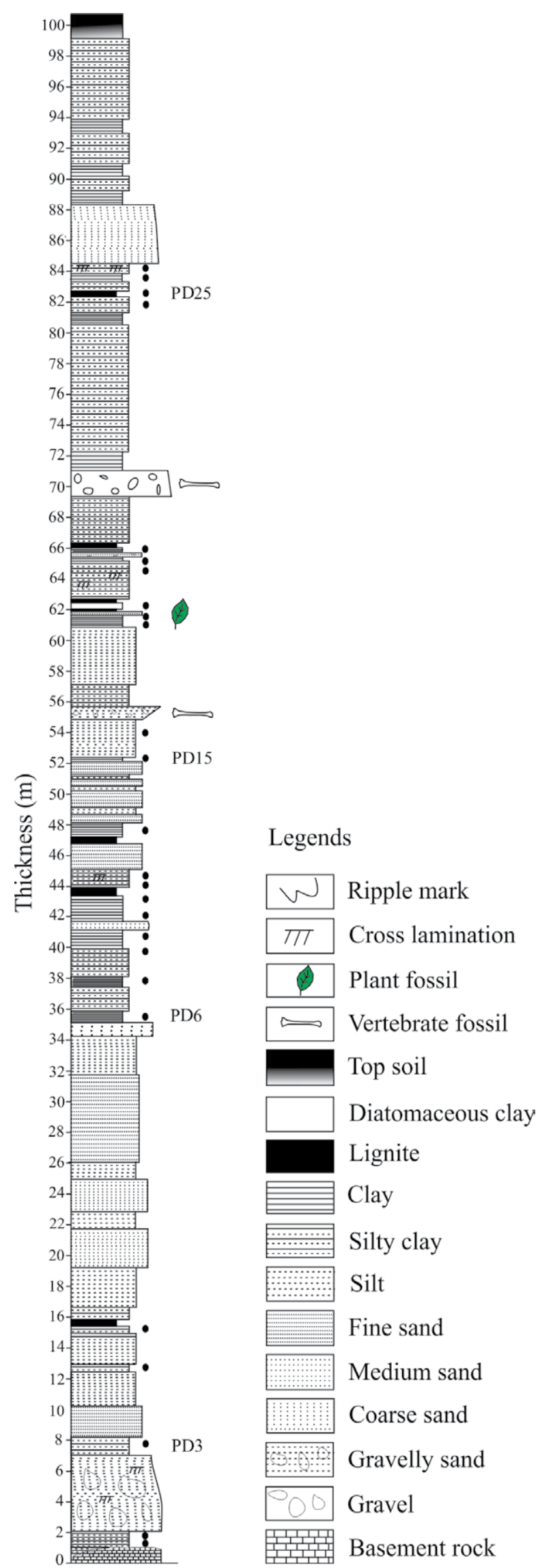

Fig. 3: Lithostratigraphy of the Lukundol Formation (basal part) exposed at Pharsidol. 

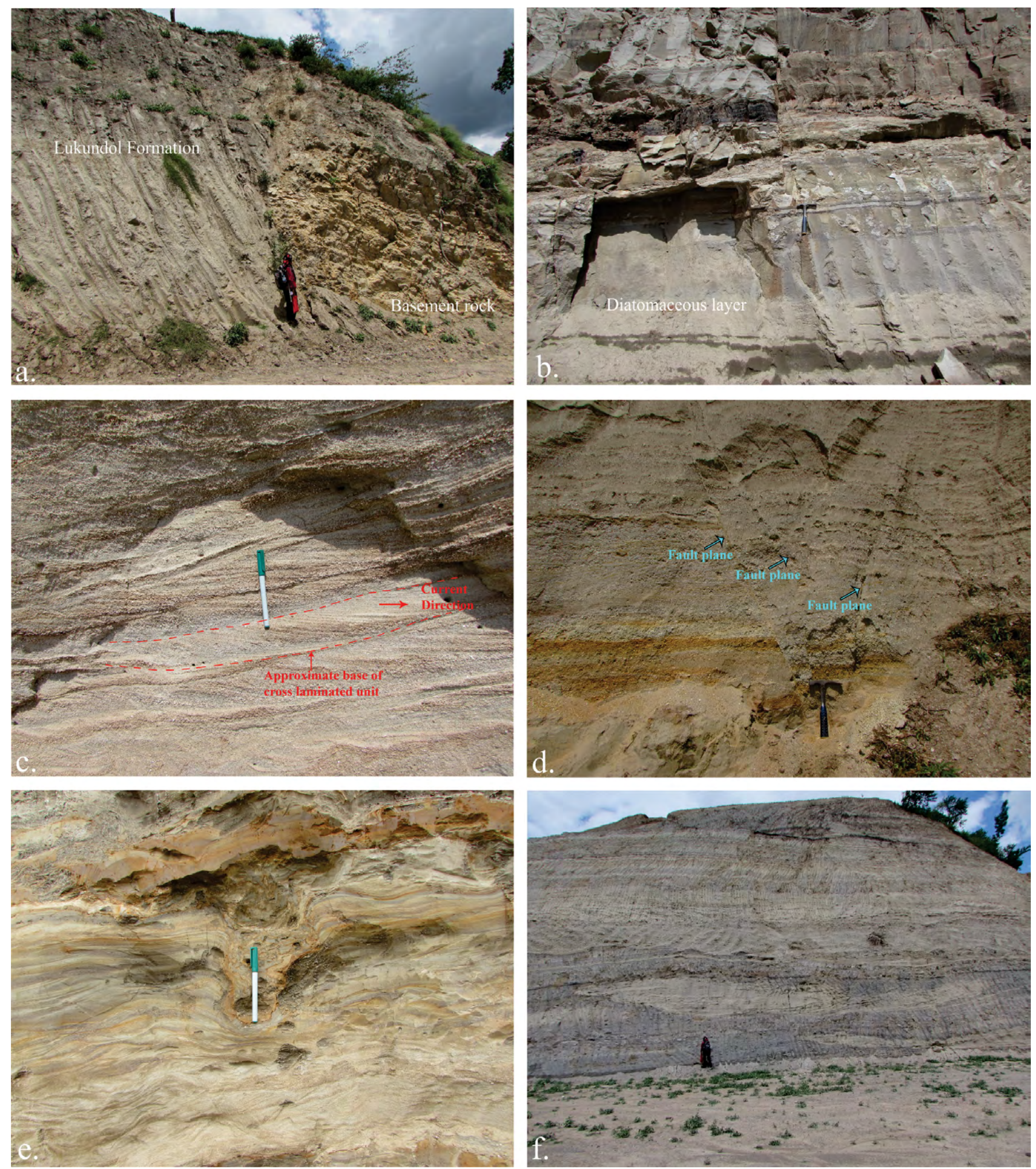

Fig. 4: (a). The basal part of the Lukundol Formation unconformably resting over the Lower Palaeozoic rocks of the Phulchauki Group of the Kathmandu Complex. To the little south of this exposure, the basal part of this formation consists of conglomerate which is named as Tarebhir Conglomerate (Sah et al. 1995; Sakai 2001), (b). Layer of diatomaceous clay in the middle part of the exposure. Thickness of diamatoceous clay is about $1 \mathrm{~m}$. There are several thin layers in different horizon, (c). Cross lamination in coarse to medium sand indicating fluvial influence in the depositional system, (d). Synsedimentary faults in a sand bed indicating the tectonic disturbances during the deposition, (e). Synsedimentary flow structures in fine sand and silt layers. Distorted cross laminations and climbing ripples also indicate the frequent disturbances during sedimentation. The synsedimentary faults and flow structures are evidences of paleoearthquake, (f). Gravel, sand, silt and silty clay layers at the upper section of this exposure. The beds of the Lukundol Formation are gently dipping (less than $10^{\circ}$ ) towards north. Northward tilting of lake sediments is due to activation of Main Boundary Thrust in the southern part of the Kathmandu Basin (Kizaki 1994). 


\section{RESULTS}

The Lukundol Formation is very rich in plant fossils which help to understand the paleoclimatic evolution. Altogether 105 species of plants belonging to 45 genera and 37 families were identified (Plates I-III). The list of pollen and spores from Lukundol Formation are listed in Table 1. The plants include trees, shrubs, herbs, aquatic plants and ferns. On the basis of abundance and diversity of climate indicating taxa the pollen diagram of the Lukundol Formation at Pharsidol section can be divided into 3 pollen zones (Fig. 5). The individual floral character of each pollen zone are described below.

\section{Pollen assemblage and Pollen Zones}

\section{Pollen assemblage zone PD-I}

This zone is characterized by the dominance of pteridophyte spores $(21.83 \%-71.82 \%)$, followed by herbaceous plants (22.73\%-47.16\%) and finally trees and shrubs (5.45\%-33.8\%). Tree pollen is dominated by broad leaved taxa Quercus $(10 \%$ 20\%). Coniferous trees comprise mainly Pinus (5\%-25\%), Podocarpus (0.5\%-5\%), Picea and Tsuga (0.5\%-2\%). Abies is absent in this zone. Alnus and Oleaceae are less than $1 \%$. The herbaceous plants are dominated by Cyperaceae $(6 \%-25 \%)$ and Poaceae (10\%-15\%), accompanied by Polygonum (1\%-5\%), Compositae $(1 \%-10 \%)$, Liliaceae $(<2 \%)$ and Chenopodiaceae $(<1 \%)$. Pteridophytes are represented by Lygodium (5\%-30\%), Polypodiaceae (15\%-25\%), Pteris $(0.5 \%-5 \%)$, Cyatheaceae $(<1 \%)$ and other trilete spores $(0.5 \%-25 \%)$.

\section{Pollen assemblage zone PD-II}

This zone is characterized by the increase in species number than that of PD-I zone. Quercus shows its dominance as in the first zone. The frequency of Quercus ranges from $0.5 \%$ to $40 \%$. Here the frequency of Pinus and Picea also increases. The percentage of Pinus is 5 to $30 \%$ and Picea is 0.5 to $5 \%$. The other gymnosperms, Tsuga (0.5\%-3\%) and Podocarpus $(0.5 \%-7 \%)$ show their presence in almost the same way as in the first zone. Similarly, the presence of Abies $(<2 \%)$ mark the distinguishing feature for this zone as it is completely absent in the previous zone. Alnus and Oleaceae retain the same proportion as in the first zone. Different species of herbaceous plants showed their presence in the second zone in comparison with the pollen zone PD-I. The presence of aquatic plants Trapa and Typha is the most distinguishing feature of this zone. The pollen of Sapindaceae family also show its presence in this zone which is absent in the other zones. Trapa (10\%) and Typha $(0.5 \%)$ are present in this zone and completely absent in the other zones. Cyperaceae (20\%-40\%) increase distinctly. Poaceae ( $1 \%-15 \%)$ retains the same proportion. Pteridophyte spores are dominant reaching the value by $(9.22 \%-82.11 \%)$. Polypodiaceae (1\%-60\%), Lygodium (1\%-35\%) and other triletes $(0.5 \%-25 \%)$ show a slight increase in proportion.

\section{Pollen assemblage zone PD-III}

In this zone trees and shrubs (2.78\%-34.76\%) and herbaceous plants $(17.86 \%-38.53 \%)$ decline but pteridophyte spores (36.19\%-79.37\%) increase. The dominating Quercus in the pollen zone PD-II shows a decrease in PD-III zone. Similarly, the percentage of Pinus (1\%-25\%) also witnessed a slight decrease. Other gymnosperms Picea and Tsuga remain at very low proportions whereas Abies is completely absent here. The herbaceous plants include Chenopodiaceae, Artemesia, Compositae, Leguminosae, Apiaceae, Myriophyllum, Malvaceae, Myrica less than 1\% in proportion. Cyperaceae (10\%-20\%) also witnessed a slight decrease. Among the pteridophyte spores the percentage of Lygodium (3\%-20\%) declined as compared with the previous zones whereas Polypodiaceae showed prominent rise. Trilete spores retain almost the same proportion in all the three zones.

\section{DISCUSSION AND CONCLUSION}

The individual palynomorph indicates individual plant species grown during the specific period of time. Among the 27 samples collected from different horizons of the Lukundol Formation, not all the samples were rich in palynomorphs. The diatomaceous layer and the lignite layer were the richest samples whereas clay layer was moderately rich and the silty clay layer was poor in palynomorphs. The diatomaceous clay and the lignite form in a wide range of environment passing through different stages of alteration from their original composition. Thus, these are made up of variety of organic constituents. The lignite consists predominantly of the remains of vascular plants and under anaerobic conditions, many organic complexes decompose only partly, forming peat, lignite and coal dependent upon the degree of peatification and coalification to which they have been subjected (Bruch and Pross 1999). In order to extract the climatic information of the past vegetation, certain taxa such as Pinus, Abies, Picea, Podocarpus, Quercus, Betula, Castanopsis, Juglans, Poaceae, Cyperaceae, Polygonaceae, Compositae, Chenopodiacae etc. were taken in consideration as they carry unique habitat and ecological characters.

The lower most zone PD-I shows the dominance of pteridophyte spores followed by herbaceous plants and then trees and shrubs. The dominant species among the gymnosperm was Pinus which grows widely at about 1100$4100 \mathrm{~m}$ altitude in sub-tropical to temperate climate (Press et al. 2000). Other gymnosperms such as Picea, Podocarpus and Tsuga were very low in proportion whereas Abies is completely absent. Among the other angiosperm trees Quercus shows its dominance. Quercus grows in sub-tropical to temperate zone (450-3800 m). The herbaceous plants show the dominance of Cyperaceae and Poaceae with few proportions of Chenopodiaceae, Compositae, Polygonum and Liliaceae. Cyperaceae, Polygonum and Liliaceae mainly indicate moist environment while Poaceae indicates the dry environment. Pteridophytes like Lygodium, Selaginella and Polypodiaceae are found in wet and shady slopes. Thus, the presence of the different taxa along with high proportion of Quercus and Pinus sp. shows that the vegetation of the pollen zone PD-I was subtropical and climate was warm. 
Maharjan et al.

Table 1: List of identified pollen and spore taxa from the Pharsidol section (Lukundol Formation).

\begin{tabular}{|c|c|c|c|c|}
\hline S.N & Division & Family & Species & No. of Species \\
\hline 1 & \multirow{5}{*}{ Gymnosperm } & \multirow{4}{*}{ Pinaceae } & Abies & 1 \\
\hline 2 & & & Picea & 2 \\
\hline 3 & & & Pinus & 1 \\
\hline 4 & & & Tsuga & 2 \\
\hline 5 & & Podocarpaceae & Podocarpus & 1 \\
\hline 6 & \multirow{30}{*}{ Angiosperm (Dicotyledon) } & Acanthaceae & Strobilanthes & 1 \\
\hline 7 & & Apiaceae & Apiaceae gen. indet. & 1 \\
\hline 8 & & Aquifoliaceae & Ilex & 1 \\
\hline 9 & & Balsaminaceae & Impatiens & 1 \\
\hline 10 & & \multirow{2}{*}{ Betulaceae } & Alnus & 2 \\
\hline 11 & & & Betula & 1 \\
\hline 12 & & Brassicaceae & Brassicaceae gen. indet. & 1 \\
\hline 13 & & Caryophyllaceae & Caryophyllaceae gen.indet. & 1 \\
\hline 14 & & Chenopodiaceae & Chenopodiaceae gen.indet. & 2 \\
\hline 15 & & \multirow{2}{*}{ Compositae } & Artemisia & 2 \\
\hline 16 & & & Comositae gen. indet. & 5 \\
\hline 17 & & Dipsacaceae & Dipsacus & 1 \\
\hline 18 & & Elaeagnaceae & Elaeagnus & 2 \\
\hline 19 & & \multirow{2}{*}{ Ericaceae } & Rhododendron & 2 \\
\hline 20 & & & Ericaceae gen. indet. & 2 \\
\hline 21 & & Fabaceae & Leguminosae gen. indet. & 1 \\
\hline 22 & & \multirow{2}{*}{ Fagaceae } & Castanopsis & 1 \\
\hline 23 & & & Quercus & 3 \\
\hline 24 & & Haloragaceae & Myriophyllum & 1 \\
\hline 25 & & Juglandaceae & Juglans & 1 \\
\hline 26 & & Labiatae & Labiatae gen. indet. & 1 \\
\hline 27 & & Malvaceae & Malvaceae gen. indet. & 1 \\
\hline 28 & & Meliaceae & Meliaceae gen. indet. & 2 \\
\hline 29 & & Myricaceae & Myrica & 1 \\
\hline 30 & & \multirow{2}{*}{ Oleaceae } & Jasminum & 1 \\
\hline 31 & & & Fraxinus & 1 \\
\hline 32 & & Polygonaceae & Polygonum & 3 \\
\hline 33 & & Sapindaceae & Sapindaceae gen. indet. & 1 \\
\hline 34 & & Trapaceae & Trapa & 2 \\
\hline 35 & & Ulmaceae & Ulmus & 3 \\
\hline 36 & \multirow{3}{*}{ Angiosperm (Monocotyledon) } & Liliaceae & Liliaceae gen.indet. & 4 \\
\hline 37 & & Poaceae & Poaceae gen.indet. & 3 \\
\hline 38 & & Typhaceae & Typha & 2 \\
\hline 39 & \multirow{7}{*}{ Pteridophyta } & Cyatheaceae & Cyathea & 2 \\
\hline 40 & & Davalliaceae & Davallia & 2 \\
\hline 41 & & Lycopodiaceae & Lycopodium & 2 \\
\hline 42 & & Lygodiaceae & Lygodium & 13 \\
\hline 43 & & Polypodiaceae & Polypodiaceae gen. indet. & 13 \\
\hline 44 & & Pteridaceae & Pteris & 4 \\
\hline 45 & & Selaginellaceae & Selaginella & 5 \\
\hline
\end{tabular}




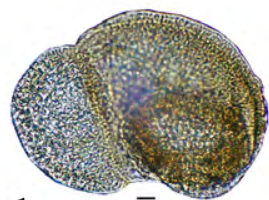

1.

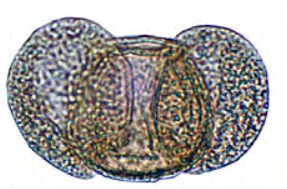

6.

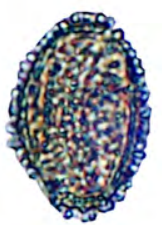

11.

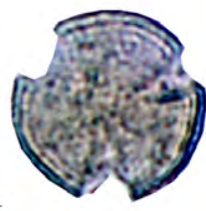

16.

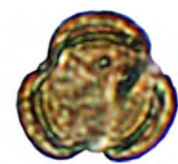

21.

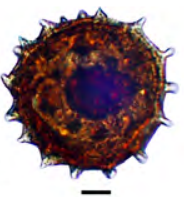

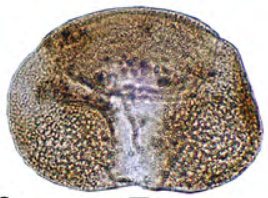

2.

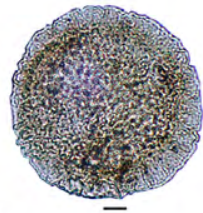

7.

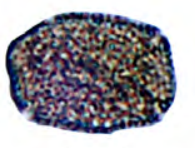

12.

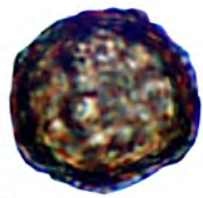

17.

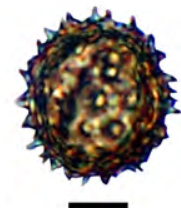

27

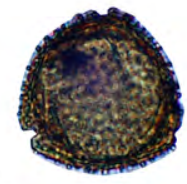

18.

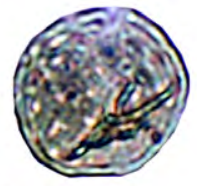

13.

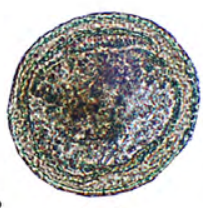

8.

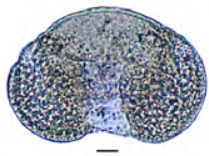

3.

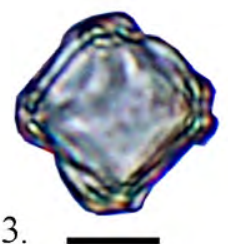

14.
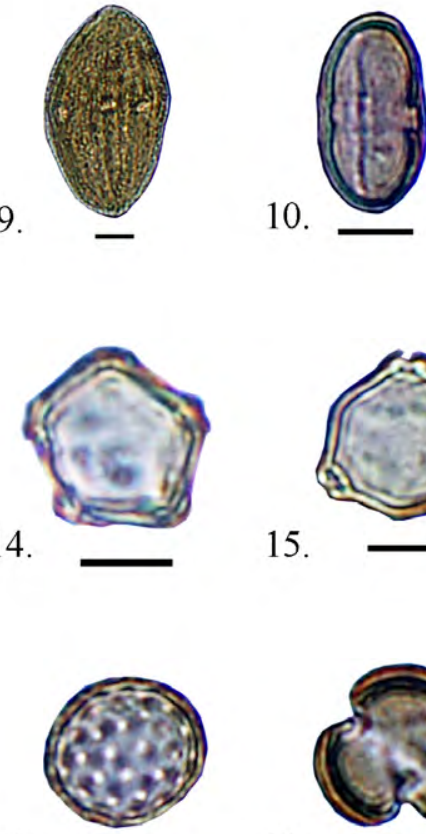

19.

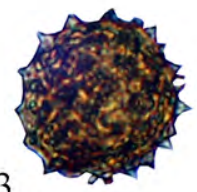

24.

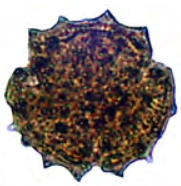

25.

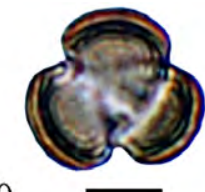

20.

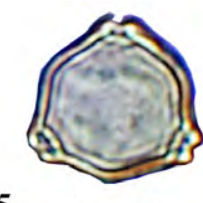

15.

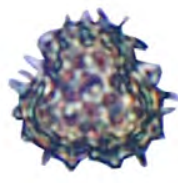

28
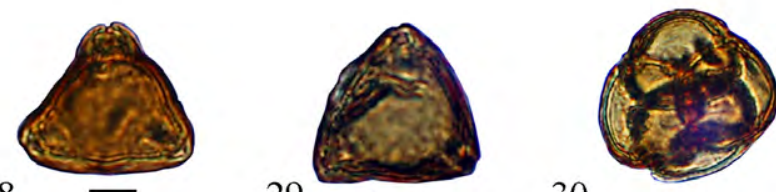

30.
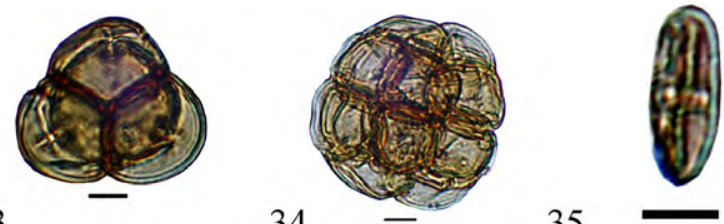

33.

34.

31.

32.

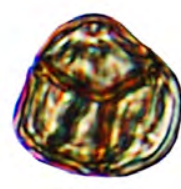

Plate I: 1. Abies sp., 2-3. Picea sp. 4-5. Pinus sp. Equatorial view and Polar view, 6. Podocarpus sp., 7-8. Tsuga sp., 9. Strobilanthes sp., 10. Apiacea gen. indet., 11. Ilex sp., 12. Impatiens sp., 13-14. Alnus sp., 15. Betula sp., 16. Brassicaceae gen. indet., 17. Caryophyllaceae gen. indet., 18-19. Chenopodiaceae gen. indet., 20-21, Artemisia sp., 22-26. Compositae gen. indet., 27. Dipsacus sp., 28-29. Elaeagnus sp., 30-31. Rhododendron sp., 32-33. Ericaceae gen. indet., 34. Leguminosae gen. indet., 35. Castanopsis sp. (Scale bar $=10 \mu \mathrm{m})$ 


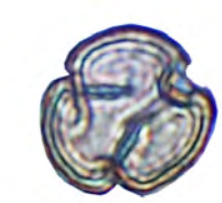

36.

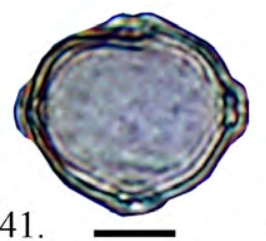

46.

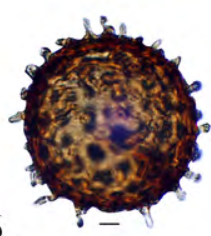

47.

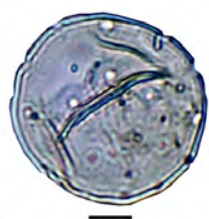

42.

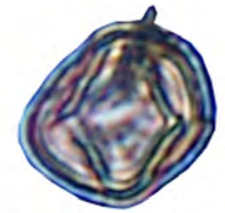

37.

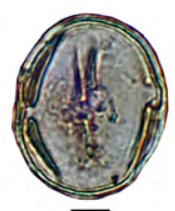

48

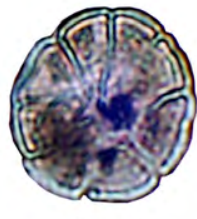

43.

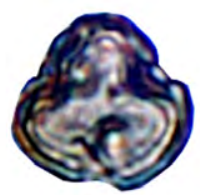

38.

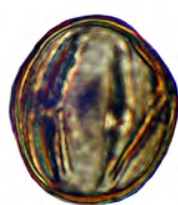

49.

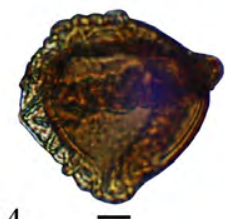

44

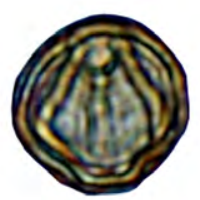

39.

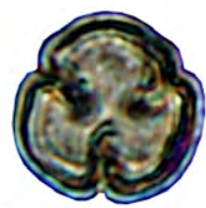

40.

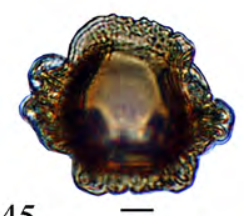

45.

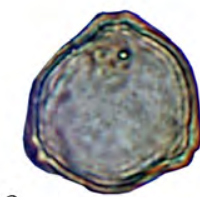

50.

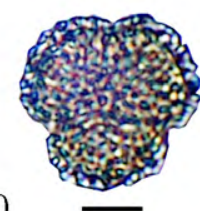

58.

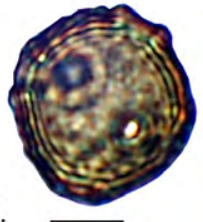

63.

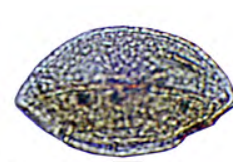

62.

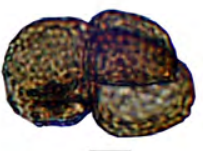

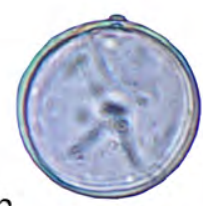
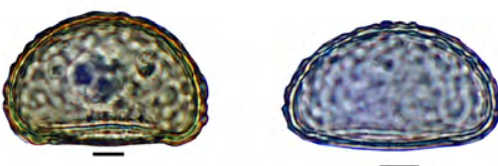

69.

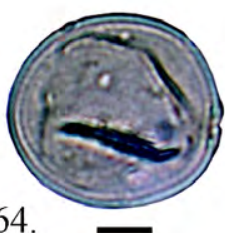

65.

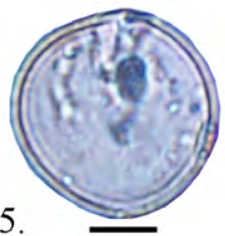

68.

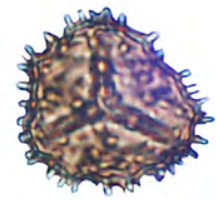

70.
55.
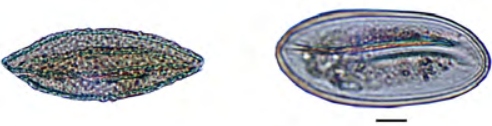

59
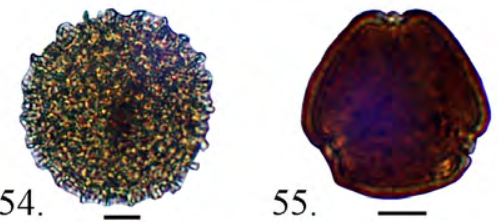

60.

Plate II: 36-40. Quercus sp. (equatorial view and polar view), 41. Myriophyllum sp., 42. Juglans sp., 43. Labiatae gen. indet., 44-45. Trapa sp., 46. Malvaceae gen. indet., 47-48. Meliaceae gen. indet., 49. Myrica sp., 50. Fraxinus sp., 51. Jasminum sp., 52-54. Polygonum sp., 55. Sapindaceae gen. indet., 56-58. Ulmus sp., 59-62. Liliaceae gen. indet., 63-65. Poaceae gen. indet., 66-67. Typha sp., 68-69. Davalliaceae gen. indet., 70. Lycopodium sp. $($ Scale bar $=10 \mu \mathrm{m})$ 


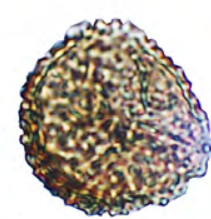

71.

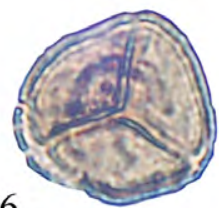

76.
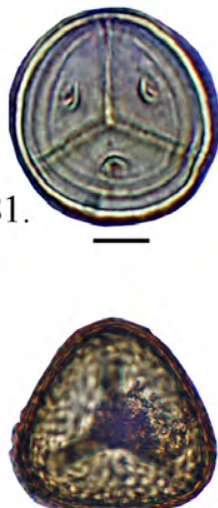

86.

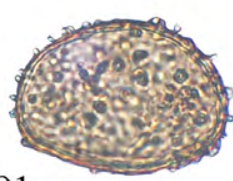

91.

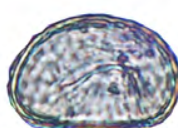

96.

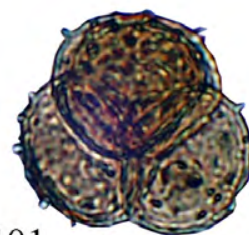

101.

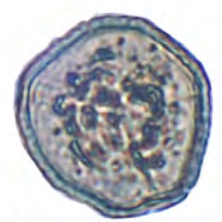

72.

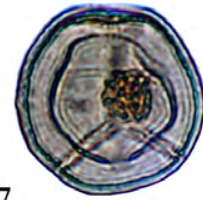

77.
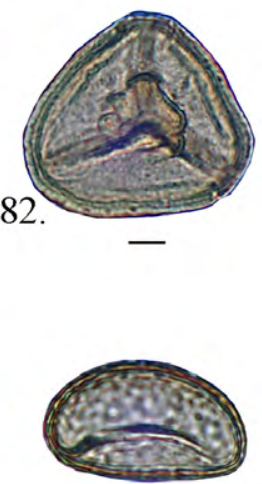

87.

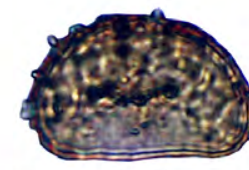

92.

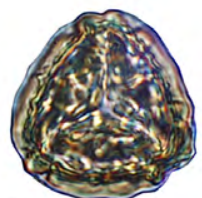

97.
78

83

88.

93.

98.

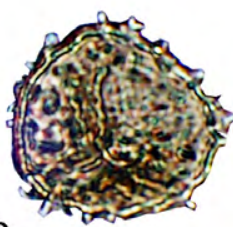

102.

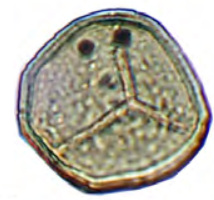

73.
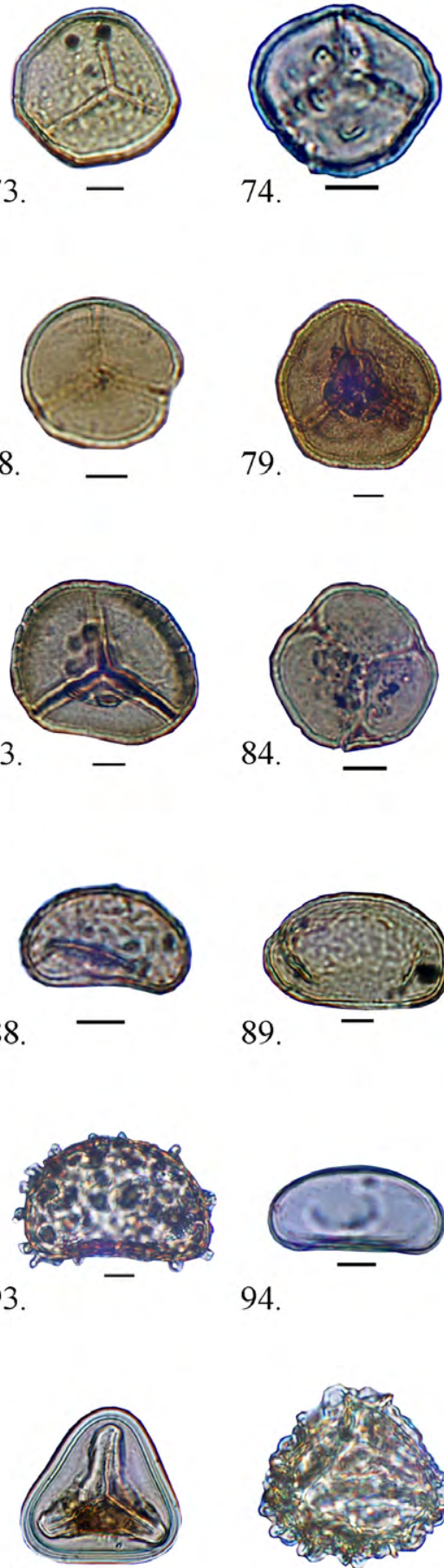

74.

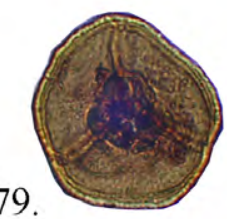

84.
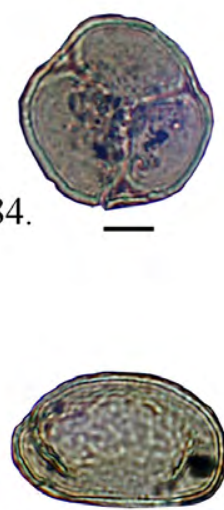

89.

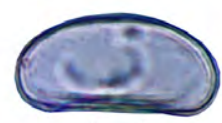

94.

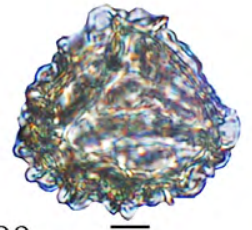

99.
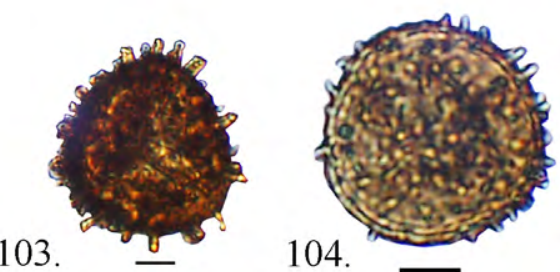

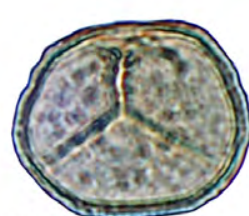

75.

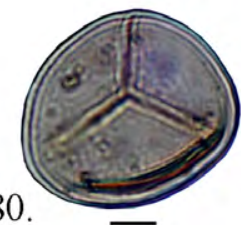

85 .
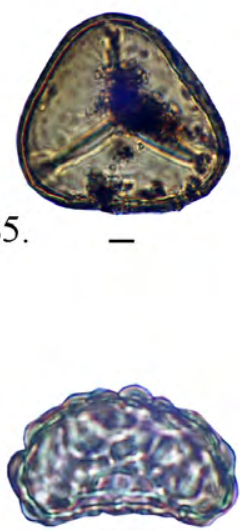

90

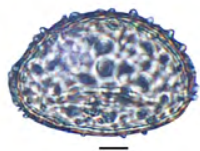

95.

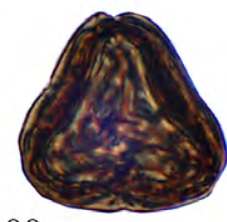

100. -

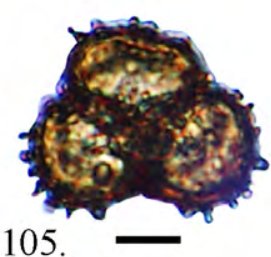

Plate III: 71. Lycopodium sp., 72-84. Lygodium sp., 85-86. Cyathea sp. 87-96. Polypodium sp., 97-100. Pteris sp., 101-105. Selaginella sp. $($ Scale bar $=10 \mu \mathrm{m})$ 


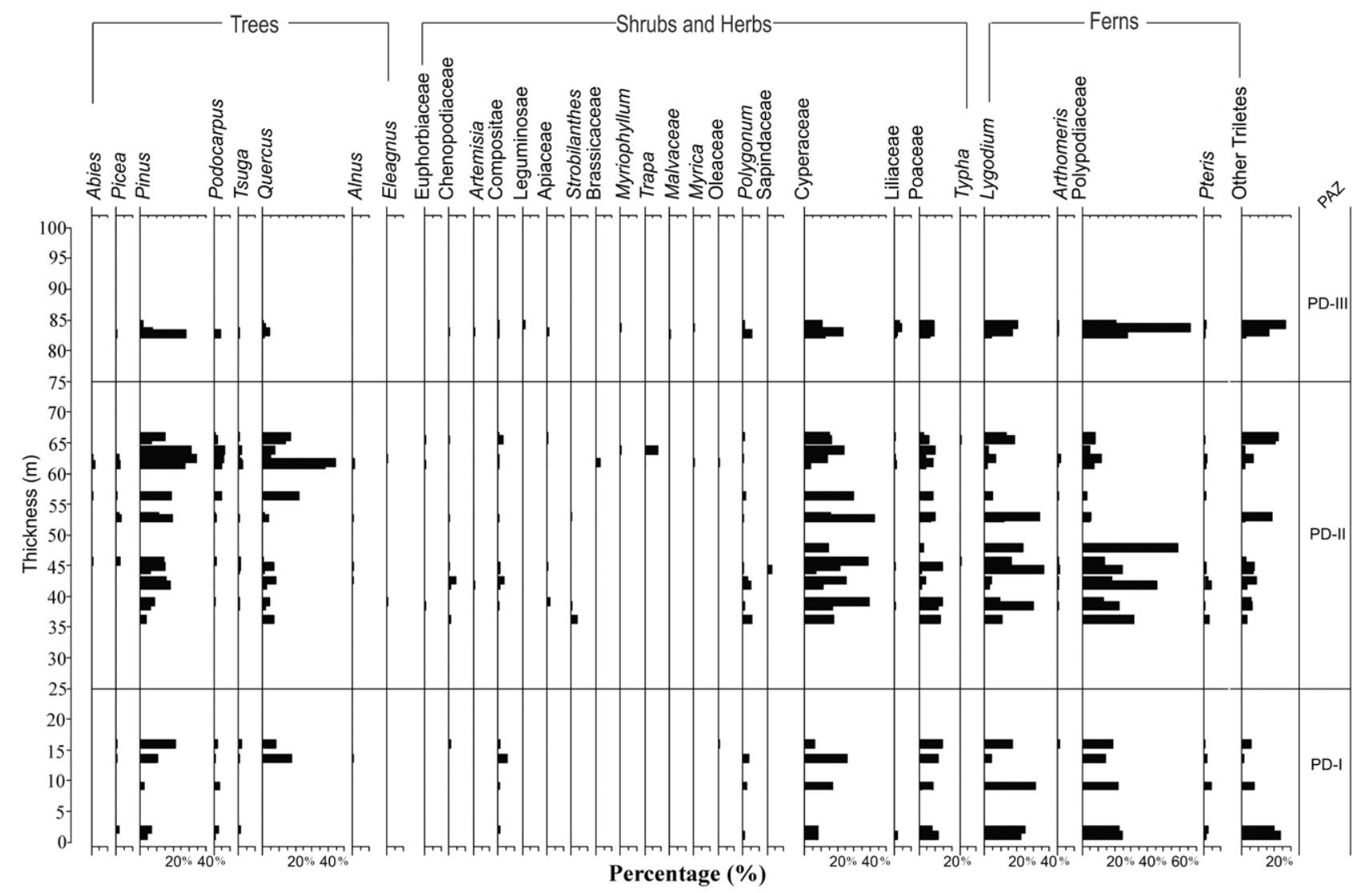

Fig. 4: Pollen diagram of the Pharsidol section (Lukundol Formation).

The second zone PD-II shows the significant increase in the number of plant species. Many changes in the vegetation can be noticed in this zone. The number of Pinus, Podocarpus, Picea and Tsuga gradually increase whereas at a certain time few Abies also show their presence which indicate cold and dry climate. Similarly, there is gradual increase in the frequency of Quercus trees. Other angiosperm trees such as Alnus, Juglans, Ulmus, Elaeagnus and different species of Ericaceae family show their presence in very low proportion. These plants indicate mixed vegetation during the deposition of the second zone. Ulmus is not found in the present natural forest in Nepal. They might have been migrated or became extinct because their ecological needs might not have been suitable for the today's environment. Therefore, the presence of Ulmus in few proportion in this zone highly suggests cold climate during the deposition of second zone. Similarly, the presence of Juglans also points to cold and dry climate. The herbaceous plants include Chenopodiaceae, Artemisia, Compositae, Apiaceae, Strobilanthes, Brassicaceae, Myriophyllum, Trapa, Polygonum, Cyperaceae, Liliacea, Poaceae and Typha. The aquatic species like Typha and Trapa are present at the uppermost part which indicates swampy condition around the lake. Similarly, the increase in the proportion of pteridophytes like Lygodium, Polypodiaceae also shows the moist and swampy environment. Hence, we can conclude that there was no uniform climate during the deposition of the second zone.
The uppermost zone i.e. PD-III is characterized by the decrease in number of gymnosperms and angiosperms whereas the pteridophytes are dominant. The pteridophytes such as Lygodium, Polypodiaceae and other triletes grow in humid and swampy areas. The herbaceous plants consist of Cyperaceae, and Polygonum which indicates the wet condition. The decrease in proportion of gymnosperms and other trees such as Quercus shows that the climate was humid and warm during the deposition of the uppermost zone. Earlier palynological investigation from the other section of the Lukundol Formation revealed abundance of Pediastrum (Fuji and Sakai 2002; Yoshida and Igarashi 1984), but it was absent from the Pharsidol section. The abundance of Pediastrum suggests the deeper water condition (Suping et al. 2013). Since it is absent in the study area, it suggests the lowering of water level during the deposition. During the deposition of the lower horizons of the Lukundol Formation, as far as it is exposed, climate may have been relatively mild or warmer and moister than that of present climate and somewhat dry to moister in the upper horizons (Yoshida and Igarashi 1984; Bhandari and Paudayal 2007). Thus, this study shows that the climate was warm and moist in the lower and upper part while cold and moist in the middle part. In the middle part, the new plants appeared and the plants that were found in the basal part also increased in their number which suggests that the climate during the deposition of the middle part was very favorable for the plants to grow. 


\section{ACKNOWLEDGEMENTS}

We would like to thank Central Department of Geology and Head of the Department Prof. Lalu Paudel for providing all the possible field equipments and laboratory facilities.

\section{REFERENCES}

Academia Sinica, 1982. Angiosperm pollen flora of tropic and subtropic of China. Academia Sinica, $453 \mathrm{p}$.

Bhandari, S., and Paudayal, K.N., 2007. Palynostratigraphy and palaeoclimatic interpretation of the Plio-Pleistocene Lukundol Formation from the Kathmandu valley, Nepal. Jour. Nepal Geol. Soc., v. 35, pp. 1-10.

Bhandari, S., Momohara, A., and Paudayal, K.N., 2009. Late Pleistocene plant macro-fossils from the Gokarna Formation of the Kathmandu valley, central Nepal. Bull. Dept. Geol., Tribhuvan University, Kirtipur, Kathmandu, Nepal, v. 12, pp. 75-88.

Bhandari, S., Paudayal, K.N., and Momohara, A., 2010. Late Pleistocene plant macro-fossils from the Thimi Formation (Madhyapur Thimi section) of the Kathmandu valley, central Nepal. Jour. Nepal Geol. Soc., v. 40, pp. 31-48.

Bruch, A.A., and Pross, J., 1999. Palynomorph extraction from peat, lignite and coal. In: Jones, T.P., and Rowe, N.P. (Eds.). Fossil Plants and Spores: modern techniques. Geol. Soc. London, pp. 26-30.

Dhoundial, E.P., 1966. Investigation of lignite deposits in Kathmandu valley, Nepal. Geological Survey of India Report (Unpublished), $34 \mathrm{p}$.

Dongol, G.M.S., 1985. Geology of the Kathmandu fluvial lacustrine sediments in the light of new vertebrate fossil occurrences. Jour. Nepal Geol. Soc., v. 3, pp. 43-57.

Dongol, G.M.S., 1987. The stratigraphic significance of vertebrate fossils from the Quaternary deposits of the Kathmandu Basin, Nepal. Newsletters on Stratigraphy, v. 18, pp. 21-29.

Ferguson, D.K., Zetter, R., and Paudayal, K.N., 2007. The need for the SEM in Palaeopalynology. Comptes Rendus Palevol, v. 6(6-7), pp. 423-430.

Fujii, R., and Sakai, H., 2002. Paleoclimatic changes during the last 2.5 myr recorded in the Kathmandu Basin, central Nepal Himalayas. Jour. Asian Earth Sci., v. 20, pp. 255-266.

Gupta, H.P., and Sharma, C., 1986. Pollen Flora of North-West Himalaya. Indian Association of Palynostratigraphers. Janki Bhawan, India, $181 \mathrm{p}$.

Hesse, M., Halbritter, H., Zetter, R., Weber, M., Buchner, R., FroschRadivo, A., and Ulrich, S., 2009. Pollen Terminology: An Illustrated Handbook. Springer, Wien, 223 p.

Igarashi, Y., Yashuda, M., and Tabata, H., 1988. History of vegetation and climate in the Kathmandu valley. Proc. Indian Nat. Sci. Aca., v. 54A(4), pp. 550-563.

Kral, F., and Havinga, A. J., 1979. Pollenanalyse und Radicarbondateirung an Proben der oberen Teile der Sedimentserie des Kathmandu-Sees und ihre vagetationgeschichtliche Interpretation, Sitz. Ber. Öst. Akad. Wiss. math. Nat. Kl. Abt. I, v. 188(1-10), pp. 45-61.

Kizaki, K., 1994. An outline of the Himalayan upheaval-a case study of the Nepal Himalayas. Japan International Co-operation Agency (JICA), pp. 1-127.
Mittre, V., and Sharma, C., 1984. Vegetation and climate during the Last Glaciation in the Kathmandu valley, Nepal. Pollen et Spores, v. XXVI(1), pp. 69-94.

Paudayal, K.N., and Ferguson, D.K., 2004. Pleistocene Palynology of Nepal. Quat. Int., v. 117, pp. 69-79.

Paudayal, K.N., 2005. Late Pleistocene Pollen Assemblages from the Thimi Formation, Kathmandu valley Nepal. The Island Arc, v. 14, pp. 328-337.

Paudayal, K.N., 2006. Late Pleistocene Pollen Assemblages from Gokarna Formation (Dhapasi section, Kathmandu valley, Nepal. Jour. Nepal Geol. Soc., v. 33, pp. 33-38.

Paudayal, K.N., 2011a. Palynological assemblages from the Late Pleistocene sediments of the Patan Formation in Kathmandu valley and their climatic implications. Bull. Dept. Geol., Tribhuvan University, v. 14, pp. 59-66.

Paudayal, K.N., 2011b. High resolution palynostratigraphy and climate from the Late Quaternary Besigaon section belonging to Gokarna Formation in the Kathmandu valley. Jour. Strat. Asso. Nepal, v. 7, pp. 33-38.

Paudel, M., and Sakai, H., 2008. Stratigraphy and depositional environments of basin fill sediments in southern Kathmandu valley, central Nepal. Bull. Dept. Geol., Tribhuvan University, Kathmandu, Nepal, v. 11, pp. 61-70.

Press, J.R., Shrestha, K.K., and Sutton, D.A., 2000. Annonated checklist of the flowering plants of Nepal. The Natural History Museum, London. $430 \mathrm{p}$.

Punt, W., Blackmore, S., Nilsson, S., and Le Thomas, A., 1994. Glossary of pollen and spore Terminology. LPP Foundation, Utrecht, the Netherlands, $71 \mathrm{p}$.

Sah, R. B., Paudel, M., and Ghimire, D., 1995. Lithological successions and some vertebrate fossils from the fluviolacustrine sediments of the Kathmandu valley, central Nepal. Nahson Bulletin, v. 5-6, pp. 21-27.

Sakai, H., 2001. Stratigraphic division and sedimentary facies of the Kathmandu Basin Group, central Nepal. Jour. Nepal Geol. Soc., v. 25, (Sp. Issue), pp. 19-32.

Sakai, T., Gajurel A.P., Tabata H., Ooi N, Takagawa T., Kitagawa, H., and Upreti, B.N., 2008. A Revised Lithostratigraphy of fluviolacustrine sediments comprising Northern Kathmandu Basin in central Nepal. Jour. Nepal Geol. Soc., v. 37, pp. 25-44.

Suping, L.I., Ferguson, D.K., Wang, Y., Jinfeng, Li., and Yao, J., 2013. Climate reconstruction based on pollen analysis in Inner Mongolia, North China from 51.9 to 30.6 ka B.P. Acta Geologica Sinica (English edition), v. 87, pp. 1444-1459.

Wang, F., Chien, N., Zhang, Y., and Yang, H., 1995. Pollen Flora of China. Xinhua Bookstore Beijing, second edition, v. 2, 437 p.

West, R.M., Dongol, G.M.S., Munthe, J., Hutchinson, J.H., and Gupta, V.J., 1988. Late Neogene and Quaternary Geology, paleontology and paleoenvironment of the Kathmandu valley, central Nepal and the Churia Hills, western Nepal. The paleoenvironment of east Asia from the Mid Tertiary. Proceedings of the second conference (Ed. P. Whyte et al.) v. II, pp. 916-936.

Yoshida, M., and Gautam, P., 1988. Magnetostratigraphy of PlioPleistocene lacustrine deposits in the Kathmandu valley, central Nepal, Proc. Indian Nat. Sci. Aca., v. 54 (A), pp. 410-417.

Yoshida, M., and Igarashi, Y., 1984. Neogene to Quaternary lacustrine sediments in the Kathmandu valley, Nepal. Jour. Nepal Geol. Soc., v. 4, pp. 73-100. 